\title{
ICT APPROPRIATION BY SMALL BUSINESSES
}

\author{
An interplay between home and work
}

\author{
Jo Pierson \\ SMIT, Vrije Universiteit Brussel, Brussels, Belgium ${ }^{35}$.
}

Key words: ICT, Self-Employers and Micro-Enterprises (SEME), User research, Work/Leisure, Access. Social constructivism.

\begin{abstract}
The paper explores the specificity of appropriation, i.e. adoption and usage, of information and communication technology (ICT) by small businesses with less than 10 employees, also denoted as self-employers and micro-enterprises (SEMEs). Starting from an interpretative viewpoint we design a functional classification of ICT based on 'transaction-oriented' and 'knowledge-oriented' use. The internal and external factors that could enable and constrain these uses are highlighted. To illustrate this approach we explore the appropriation of Internet services in the case of public accountants in Flanders (Belgium). Our goal is to indicate how technological and economic aspects of ICT appropriation are socially embedded.
\end{abstract}

\section{INTRODUCTION}

The paper discusses the interpretative, social and technological aspects that play a part in the actual adoption and usage of (ICT) information and communication technology by SMEs (Small- \& Medium-sized Enterprises) with less than 10 employees. ${ }^{36}$ More specifically this refers to the 'selfemployers ${ }^{37}$, as well as the 'micro-enterprises ${ }^{38}$. Together they make up the

Research Assistant for the Fund for Scientific Research - Flanders (Belgium) (F.W.O.)

The research project on this issue ('Socio-economic and regulatory conditions for the innovation of multimedia services in Flanders') is part of the Medialab-programme, a social research initiative focussing on information and communication technologies and financed by the Flemish government.

Self-employed people that do not employ anyone else, so with no personnel [7]

109 
so-called SEMEs (Self-Employers \& Micro-Enterprises). This comprehends the diverse collection of all small-scale entrepreneurs, craftsmen, retail businesses and liberal professions. We will illustrate the issue of ICT appropriation by a case study on public accountants who are self-employed with no personnel and those who are employer in an office with less than 10 employees. The central question is how Internet applications are appropriated and interpreted amidst the activities and routines of everyday life of work and home..$^{39}$

The relevance to focus the research on the appropriation of ICT by the SEMEs, as described above, can be situated on three levels: social, theoretical and economic. From a social viewpoint it is essential to involve all sections of society in the diffusion of communication technologies [14]. This refers to the residential home public as well as to the small-scale professional public. The economic relevance refers to the fact that small businesses with less than 10 employees represent almost $93 \%$ of all European enterprises, while being the only category which creates more jobs than it cuts [9]. However we notice that there is still a fundamental lack in social-theoretical knowledge with regards the latter group. The dominant discourse departs from an economic or technological logic. Moreover the factors for success and failure of ICT with large organisations are usually uncritically extrapolated to the SEME context. Yet in reality we are dealing with totally different worlds of experience, which in the case of SEMEs resembles largely the home context.

\section{IMPLICIT GOALS IN BUSINESS PRAXIS}

A business embodies different kinds of activities. This includes activities in purchase, production, marketing, administration, human resources, training, sales etc. The base line is generating income through creating value. This value is represented financially by 'profit', which in economic theory is sometimes seen as the return for entrepreneurs for taking risks [3]. Therefore it is commonly accepted that to run a business one needs to pass through an economic value chain of input, processing and output. In order to facilitate this value chain exchanges of information and communication are indispensable. This ranges from very basic activities like business meetings to sophisticated computer applications like enterprise resource planning (ERP) systems. According to Freeman [10] ICT is capable of revolutionising

38 People or businesses that employ between 1 and 9 persons. See terminology in recommendation for redefinition of 'SME' by the European Commission (1997).

39 The findings presented in the case study are based on the interim report: [19]. 
the processes of production and delivery of goods and services. The sum of all these kind of technologies and applications we call 'transaction-oriented ICT'.

Nevertheless the value chain needs to be supported by a certain degree of knowledge specific to the profession. In order to keep in touch with recent developments it is obligatory to consult information resources that can contribute to the upgrading of professional expertise. We discern four important sources. First the colleagues (or competitors), for example for the exchange of experiences on common problems. Training and consulting services can offer an extra support for the management of one's business. Third the professional organisations that promote the interests of the profession, can also be a relevant information source. Finally the authorities on different echelons each have a possible role in the information gathering and knowledge built-up. To the degree that all these kind of communications are being enabled by technology, we call the latter 'knowledge-oriented ICT'.

Communication in general, so also within a working environment, can develop along four different patterns.

Table 1. Four patterns of information traffic

\begin{tabular}{|c|c|c|}
\hline INFORMATION & $\begin{array}{l}\text { Information store } \\
\quad=\text { CENTRAL }\end{array}$ & $\begin{array}{l}\text { Information store } \\
=\text { INDIVIDUAL }\end{array}$ \\
\hline $\begin{array}{l}\text { Control of time \& choice of } \\
\text { subject = CENTRAL }\end{array}$ & $\begin{array}{c}\text { Allocution } \\
\text { e.g. Electronic newsletters }\end{array}$ & $\begin{array}{l}\text { Registration } \\
\text { e.g. Filling in electronic form }\end{array}$ \\
\hline $\begin{array}{l}\text { Control of time \& choice of } \\
\text { subject = INDIVIDUAL }\end{array}$ & $\begin{array}{c}\text { Consultation } \\
\text { e.g. Consulting Websites }\end{array}$ & $\begin{array}{c}\text { Conversation } \\
\text { e.g. Send \& receive E-mail }\end{array}$ \\
\hline
\end{tabular}

These patterns of information traffic applies for knowledge oriented as well as transaction oriented ICTs. Based on the aforementioned assumptions we construct the scheme in Figure 1.

\section{FACTORS ENABLING AND CONSTRAINING ICT APPROPRIATION}

\subsection{SEME specificity}

The possibilities offered by technologies (like Internet) for facilitating and optimising the communication and information exchange at the workplace are countless. Revolutionary visions like the paperless office have 
made the workplace as one of the major focal points of efforts to apply ICTs. However these efforts in many cases led to failures due to a low degree of adoption. Because the potential user at the workplace is an economic entity, suppliers often assume a purely rational behaviour on the side of the potential professional user. This kind of economic logic has for a long time dominated the study on the implementation of communication systems in businesses. Yet a lot of research has already pointed out the necessity of embedding this kind of pure economic reasoning within a broader socioscientific approach by introducing social, cultural, political or psychological aspects [17], [5], [8], [1] \& [15]. Even within economic theory, some schools fundamentally question the notion of the rational maximising actor or 'homo economicus' [23]. Recent literature in institutional and evolutionary economics as well as on 'entrepreneurship' demonstrates this and offers some alternative views.

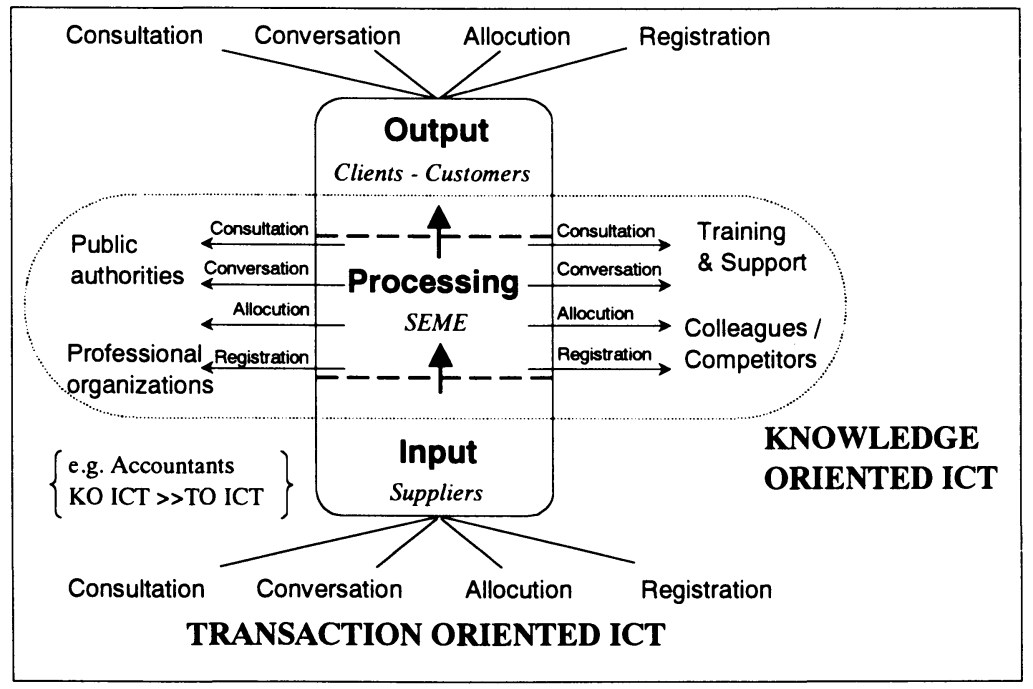

Figure 1. ICT classification

This broadening of the socio-scientific scope is even more relevant when we study the ICT appropriation by SEMEs. The decision power in these very small businesses is more centred around one person, the entrepreneur himself or herself. As a consequence personal and social motives, besides the professional motives, can have more influence in comparison to larger enterprises. For example in larger firms decisions with regards ICT adoption more often pass through different (hierarchical) levels, which makes it less dependent on one key person. So the decision power concerning ICT investments is more often in the hands of a group of people (decision making 
unit), sometimes going through a formal evaluation process. Explaining these kind of processes is one of the topics in organisation theory, management science and in the literature with regards organisation communication. In order to discern and concretise the enabling and constraining factors with regards adoption and usage of ICT in SEMEs, we use an adapted framework for analysis.

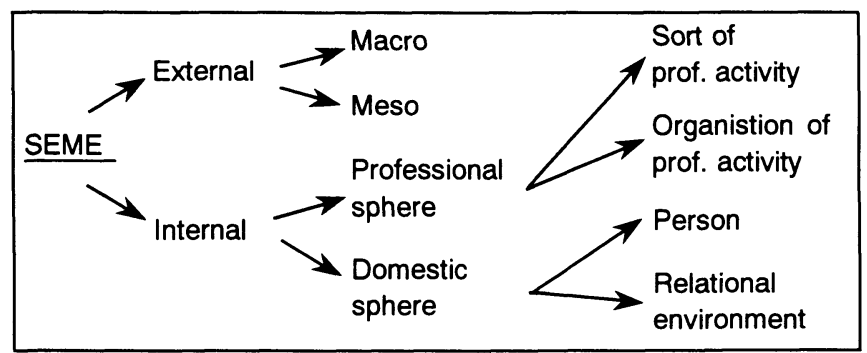

Figure 2. Adoption and use of ICT by SEMEs

In the current research stage this framework mainly serves as an exhaustive analytical checklist for exploring the technological and social aspects of the interaction between ICT and the SEME context (Figure 2). It indicates factors and characteristics that can play a part in the appropriation of ICT, seen from the viewpoint of the self-employer or the key person in the micro-enterprise. This exploration is the start for developing a more 'generic' model with regards ICT appropriation, applicable for the SEME context in general. ${ }^{40}$

\subsection{Internal \& external factors}

For the internal factors we need to conceptualise the research frame from the point of view of the user [6]. In the end it will be the (potential) user himself who determines whether and how the new technology will be appropriated within the daily life of home or work. Given that SEMEs often work within a domestic context, we must involve both spheres (see Figure 2: Professional vs. Domestic sphere). In order to explore the professional and domestic sphere in relation to ICTs, we link them with two basic kinds of relative advantage as perceived by the (potential) user, i.e. economic and

One of the goals in the research project 'Development and appropriation of information and communication technologies within the small-scale professional context: User-oriented analysis of social and technological aspects' (Doctoral scholarship - Jo Pierson; Research Assistant for the Fund for Scientific Research - Flanders/Belgium). 
social [4]. When talking about self-employed and micro-enterprises, there is an obvious link with economic advantages of ICT. From a user-oriented position the perception of the latter can be divided in two dimensions: 'entrepreneurship' and 'craftsmanship'. These dimensions relate on the one side to the organisation of professional business activity (as being an 'entrepreneur') and on the other side to the sort of professional activity (as being a 'craftsman' practising a specific profession e.g. accountant) (see Figure 2: Organisation vs. Sort of professional activity).

However besides this more economic reasoning, businesses like SMEs also experience important influences from non-economic aspects [17], [16]. This is even more true for a very small business, because of the interplay with the residential context. This leads us to what we call social relative advantage. Again we distinguish two dimensions. First the entrepreneur or the person himself, which relates to personality and personal history. Relevant aspects are general socio-demographic features (age, sex, education,...) as well as psychosocial characteristics (life style, personal traits,...). Second we discern the relational environment which includes the social network of family, friends and acquaintances. The importance of this social network for the continuation of usage was already confirmed by findings on the early use of home computers [18].

However, when dealing with SEMEs, this splitting up between professional and private is made more for analytical purposes. In reality we observe a significant overlaps between these two spheres. Given their small size and often familial character, it is obvious that in very small businesses professional motives interrelate frequently with domestic aspects [20]. This is to a certain extent comparable to the situation of home-based teleworkers. Their workplace is situated at home, which has consequences for the use of telecommunications-related or computer-related technologies. From being working machines they often migrate to home use by other members of the family. The reverse process does also occur, where domestic communication technologies are regulated by professional requisites (e.g. who answers the phone, rules about occupying the phone during working hours,...) [13]. This kind of reciprocities between professional and private sphere we find to a large degree in the realm of SEMEs.

Besides an internal micro-level approach we also need to incorporate external characteristics, the so-called macro- and meso-level of social and technological developments (Figure 2: Macro-level vs. Meso-level). Macro refers to general socio-economic situation as well as the very broad field of political, economic and social initiatives, developments and trends. Especially when dealing with the self-employed and the very small businesses, the meso-level can also have an important impact on ICT appropriation. This relates to the attitude and initiatives of (inter)professional 
organisations and other co-operation initiatives (deontology, innovativeness, etc.....).

\section{CASE: INTERNET APPROPRIATION BY PUBLIC ACCOUNTANTS}

\subsection{Research design}

As indicated, for the study on the ICT appropriation by SEMEs we explore some results of a case study with public accountants. In Belgium the liberal professions for accounting are subdivided into three certified categories: bookkeepers, public accountants and auditors. This shifts from more executive tasks for bookkeepers to more of an independent control function for auditors. The core mission of the public accountant is to give advice based on balance sheets and audit results. They also assist people and organisations in their administration with regards finance and tax issues. Sometimes this also includes legal issues.

Based on the research question a topic-list was designed which served as the guideline for conducting the in-depth interviews with different types of public accountants. The actual data collection and analysis is based on an iterative process in accordance with the 'grounded theory' principles [12], [26], [27]. ${ }^{41}$

\subsection{Key concepts}

\subsubsection{Adoption and usage}

In order to analyse the specificities of small-scale accounting businesses with regards the adoption and usage of Internet, we use the aforementioned models (Figures $1 \& 2$ ). We focus on the public accountant himself or herself who renders meaning and significance to the Internet application. More in particular we explore those factors that determine the appropriation of Internet as a means for professional activities of the public accountant (transaction and knowledge acquisition). This largely falls into two periods.

${ }^{41}$ We interviewed 20 accountants in their office, all on different places in Flanders (Dutch speaking part of Belgium). Besides 3 self-employers and 15 micro-enterprises, also 1 trainee and 1 bookkeeper where involved in the study as points of comparison. The indepth interviews took place in the period between 25 September and 8 October 1998. 
First we describe the adoption which encompasses the mental process between the first contact with the technology until the actual acquisition. This is influenced by the attitude and the evaluation of the entrepreneur, dependent on the factors indicated in Figure 2. The adoption is then a prerequisite for the second part of appropriation, the usage. To what extent the ICT is actually used depends among others on the introduction and installation, when the prior image is confronted with the first use [22]. The further career of ICT usage can be denoted as 'domestication' [25]. The technology has its impacts on the workplace arrangements while at the same time these arrangements determine the way in which the technologies are fitted in the professional praxis. With that the professional practices and the usage of Internet are directed by a twofold pursuit in every business activity, as described in Figure 1. The way Internet applications (WWW, E-mail,...) are used (knowledge and/or transaction-oriented) constitutes the point of departure of our discussion on usage.

\subsubsection{Classification}

But first whether or not Internet is adopted and used forms the basis for discerning different types of public accountants. We distinguish five different kinds of SEME accountants in relation to Internet appropriation. At the same time this will give an indication on the degree to which Internet is embedded in the professional praxis. On one side of the spectrum we discern the accountants who do not have an Internet-connection at work nor at home, the 'non-connected'. Some of them, the ex-users, have been subscribed in the past but have for some reason discontinued the subscription or did not prolong the trial subscription.

All the other public accountants do have an Internet-connection. A first subgroup is called the 'non-users'. They are connected, but they do not make use of the applications themselves. In some cases other people in the office use the Internet. In other cases the non-use is attributed to (technical) problems with the installation of Internet applications. These professionals often do not have a social network that can help them with these computer problems. Another group, the 'domestic users', has originally acquired an Internet-connection for professional motives. Yet in reality they only use Internet applications within the domestic sphere. Besides these users in the domestic sphere, we also distinguish users who use their Internet-connection almost solely for professional reasons. These 'professional users' avoid domestic use because they fear high telephone bills. Others simply do not have or want a computer at home. Finally we discern the 'double users'. These public accountants use their Internet-connection for their work as well as for pleasure at home. 


\subsection{Findings}

\subsubsection{Adoption}

Given the current hype the accountants in our case study - together with the general public - are deluged by messages in the media about Internet (Figure. 2: Macro-level). So every respondent has at least heard about Internet. Sometimes they were exposed to Internet via private or professional relations. There is a general belief among public accountants in Flanders that the Internet will inevitably become very important and will change their work fundamentally.

"I became aware that it would become something big, that would influence the society and in the end would conquer. ${ }^{, 42}(\mathrm{~A} 16)^{43}$

The mixture of inescapability on the one side and optimism on the other side is also reflected in another study. Here public accountants see the use of new media as increasingly essential for practising their profession. They state that the new information and telecommunication technologies like Internet will generate gain in efficiency and a competitive advantage [11].

This optimistic notion was one of the motives for 'double users' to acquire Internet. But for these respondents the personal interest within the domestic sphere (see Figure 2: Person), with computers as a hobby, was a more decisive factor. Because they felt at ease with the underlying technology, there was a lower threshold to adopt a new computer application like Internet.

A third motive for adoption of Internet was not to lag behind on the clients and competitors. All the respondents who use Internet for professional tasks, i.e. besides the 'double users' also the 'professional users', mention this motive. Because the client sees the public accountant as the primary adviser, he or she cannot afford to know less about new developments than the client does (Figure 2: Sort of professional activity). Even the 'non-connected' admit that when more clients should have e-mail, one cannot stay behind.

"The clientele gets younger and younger. [...] So once these people become your clients, they probably will all use e-mail. In that case you can't permit yourself not to follow. So it is almost a necessary evil. At the moment I keep my distance, but I think that in the end I'll have to give in." (A2)

${ }^{42}$ All the citations are translations of the original Dutch interviews.

${ }^{43}$ The alphanumerical code refers to the respondents, e.g. A16 refers to Accountant $\mathrm{N}^{\circ} 16$. 
As we will see further on, this kind of 'client push' is also important concept with regards ICT usage.

'Domestic users' say they want to support the interests of their children with regards Internet. This is presented as the essential motive for adoption, despite the fact that it was originally introduced for professional use. This fits with their view that Internet is still more of a 'toy' that is not (yet) adequate for the job.

\subsubsection{Usage}

Internet as symbolic object. The relation with the client is often an essential trigger for using Internet for professional reasons. This 'client push' leads to more intensive professional use because of its symbolic function. Using Internet symbolises that one keeps up with the times. When this use enables him to advise the client on Internet issues it attaches an aura of 'professionalism' to the public accountant, which is expected by most clients. Silverstone [24] describes this as 'conversion' or through the use of the technological artefact one can show one's belonging to a (elite) certain group. So despite the often little functional value of Internet use, the symbolic value is worth the effort of 'domesticating' this innovation [21].

Knowledge-oriented use. Gathering, processing, retrieving and applying the correct information is crucial for public accountants. The importance of appropriate information sources is demonstrated by the high 'information budget', which are the expenditures for professional information resources. The latter refers to basic documentation (e.g. law books, law gazette), specialist literature as well as more general background information. However these resources are still predominantly in paper.

With respect to Internet applications it appears that especially WWW is used more knowledge-oriented. According to the public accountants the Web can offer input about background information, but it is not developed sufficiently for more specialist accounting issues.

"Only peripheral information. The real 'hot' info, the info that gives a accurate answer to my question, you will not find on it." (A18)

The lack of structured and well-organised information resources on the Internet is cited as the most important obstacle for professional use.

'Double users' generally start to explore the Web for domestic reasons (e.g. hobby), which later on migrates to professional use. The latter is done when one has a specific question, which cannot be answered immediately via the standard way. In this sense WWW is no more than a sophisticated form of consulting information brochures with the advantage of larger and 
more direct availability. These searches are sometimes in function of a specific client question. In conjunction to Internet as a symbolic object, here Internet and more specific the Web is also a functional object in relation to clients.

The knowledge-oriented use of e-mail seems to be of only minor importance. We see for example that there is a lot of restraint to exchange professional experience via electronic conversations with other public accountants. Nor is there much interest for electronic magazines via e-mail (e-zines). Some 'double-users' are subscribed but only in a confined way in order to avoid information overload.

"I mean, you get somewhat the same information you also get via Fiskoloog [paper magazine on tax issues] and the other sources. So it is indeed a major problem in our line of business, that there exists a tremendous overlaps of information." (A17)

As a result the Internet applications for the moment do not offer a valid substitution for other knowledge-oriented media in accounting. At best they are used as a supplement for existing sources.

Transaction-oriented use. The use of Internet for facilitating the commercial business aspects of public accountants is a very sensitive matter. The meso level of the professional organisation (Institute of Public Accountants) plays a major part in this issue. This organisation guards over the ethical principles, which state that it is forbidden for Belgian public accountants to advertise. With the introduction of WWW there was a lot of quarrel whether a Website should be viewed as commercial communication. It is only recently that this professional organisation allows some form of Web presence.

Yet most respondents are still reserved about setting up an own Website, because they think it is forbidden by the ethical rules (Figure 1: Output). In addition they do not see the real advantage of Internet communication. Even if a potential client should have Internet access, which is rarely the case according to the respondents, most of them are not really looking for new clients. These SEMEs are satisfied with the current business size. And even if they are looking for new clients they prefer direct social contact, because the relationship is largely built on trust which is more difficult to obtain via an impersonal electronic medium. The few who have set up a site mention the larger visibility to the outside world as their motive. This is also related to the symbolic value of being perceived as a competent adviser who keeps up with the times. Nevertheless until now they did not get the response they expected for. 
Another transaction-oriented usage of Internet is the use of e-mail in their contacts with suppliers and clients (Figure 1: Input \& Output). The way in which e-mail is used is very particular. For the most part it are short informative messages and specific questions. It looks more like data transfer with a rather impersonal neutral content. Clients generally prefer personal contact when discussing their finances, because of its sensitive nature. Given the importance of personal contact and trust in the service provision of a public accountant, e-mail cannot replace regular day-to-day communication with clients.

Nonetheless some transaction-oriented ICT applications would be highly welcomed. Public accountants look forward to initiatives that could facilitate administrative obligations. The respondents refer for example to the announced electronic VAT declaration, which would enable public accountants to send in the VAT forms of clients via an online connection (Figure 1: Output - Registration). This represents a real functional advantage, because accountants gain time by shifting the deadline. Now every document has to be printed and posted in time. The respondents even plead for an enlargement of 'tele-administration' to other domains, e.g. the trade register.

"I would appreciate that tremendously, because at the moment the laborious procedures with all the paper work are very time-consuming." (A8)

\section{CONCLUSION}

We find that for Internet users, despite the apparent large degree of adoption of one Internet application (WWW) and the rather positive attitude towards another (E-mail), the picture is not so straightforward. We see that the real usage and embeddedness in the professional praxis is far from being realised in the accounting profession. This again shows that the ICT appropriation process is in fact twofold. On the hand you have the adoption and on the other hand there is the actual usage. While there is a strong mutual influence, the first does not automatically imply the second. Any analysis of ICT appropriation should therefore always integrate both parts.

Exploring the adoption and usage of an ICT like Internet by SEMEs necessitates an analysis how these technologies can or are integrated in the professional praxis. Therefore we need to focus on the key figure in the SEME, the entrepreneur-craftsman. He or she determines largely the professional praxis in the SEME business, possibly in consultation with others. The overall goal is to survive as a business, while generating earnings 
through creating value in goods or services. The key reference for all these business acts is the client.

\subsection{Client strategies}

Consequently adopting and using ICT is always - directly or indirectly related to the client. Foremost we should look for the strategies that are deployed by means of ICT in the professional praxis in order to retain the number of clients or to maximise the clientele. These strategies for client retention and client maximisation depend on the way the entrepreneur perceives and interprets the expectations of clients. In our case study we found several examples of these strategies.

With respect to client retention it became clear that being able to work with Internet is perceived by many public accountants as a necessity. As the primary adviser of clients the public accountant is convinced that clients expect a business man who keeps up with the times. Indicated as 'client push', this idea is an important motive for adopting Internet or learning to use e-mail. On the other hand several public accountants indicate 'staying small' as a desired condition. It means that they content themselves with client retention. The resulting strategy in this case for example was not setting up a Website that could attract new clients.

Other public accountants do strive for client maximisation. The accountants, perceiving their potential clients as 'Internet-minded', could choose for the strategy of developing an own Website. Yet other public accountants have more trust in their personal relations for acquiring new clients. This is illustrated by an accountant who feels no need for a system of electronic (Internet) banking. By visiting his bank regularly, he can keep a close relationship with the director. The latter sometimes refers clients, looking for an accountant, to him.

\section{$5.2 \quad$ ICT perception}

Yet the part any ICT can play within a certain strategy also depends on the way the SEME entrepreneur-craftsman perceives and experiences the ICT application in question. SEME are often so pre-occupied with their dayto-day activities that appropriation of ICT is only feasible when the technological artefact or application is perceived as 'mature' for the professional practice. When this is not the case, in other words when it is perceived as a kind of 'toy', the SEME will not be inclined to invest time or money. This appeared to be the case with many public accountants as to Internet. The perceived maturity is therefore dependent on the presence of 
certain features. Our case study indicates some essential characteristics. Professional ICT maturity arises if:

- the installation, the instruction and the usage are transparent and userfriendly, similar to the ICTs already available (e.g. telephone, specialist software) and/or;

- the ICT applications are purpose-made for a specific profession and that can therefore simplify certain professional activities (e.g. sector-specific WWW info, electronic VAT-declaration) and/or;

- the perceived critical mass of clients using it or asking for it, is large enough. This refers to the symbolic value of being perceived as a competent adviser who keeps up with the times (client push).

If on the other hand the ICT is not perceived as mature, the appropriation will depend upon the available skills of the entrepreneur himself or herself. The latter sometimes depends on his or her hobbies or interests (e.g. computer, WWW surfing). Without these skills the SEME mainly falls back on a so-called 'problem solver' in his social network (family, friends, acquaintances,...). Otherwise when maturity, skills or problem solvers are not available, the appropriation of the ICT concerned will be a problem or will just not take place. Within larger enterprises the aspect of 'maturity' is less problematic. Mostly they have the possibility of passing on the appropriation to a professional problem solver (e.g. IT-department).

\subsection{Implication}

So on a more general level our findings reject the technological deterministic thinking which states that only the technological features determine the actual implementation and use in the SEME business. At the same time our findings with regards SEMEs take the edge off the implicit assumption in economic theory that economic agents are omniscient or at least hyper-rational in their behaviour [17]. By focussing on client strategies, as well as on the way ICT applications are perceived, we can demonstrate how the ICT appropriation is constructed as a process co-determined by social aspects. An analysis of this kind advocates the idea of embedding economic analyses of technological change and small business strategy within a broader socio-scientific approach which takes into account the domestic context [5], [1].

\section{REFERENCES}

[1] Anderson, R.J., Hughes, J.A. \& Sharrock, W.W. (1989) Working for profit - The social organisation of calculation in an entrepreneurial firm. Aldershot: Avebury. 
[2] Bordewijk, J.L. \& van Kaam B. (1982) Allocutie: enkele gedachten over communicatievrijheid in een bekabeld land. Baarn.

[3] Bull, Ivan \& Willard, Gary (1996) 'Towards a theory of entrepreneurship', in: Ivan Bull, Howard Thomas \& Gary Willard (Eds.) Entrepreneurship - Perspectives on theory building. Oxford: Pergamon, 1-16.

[4] Burgelman, J.C. (1994) 'Assessing IT in the information society: The relevance of communication science and research', in A. Calabrese, S. Splichal \& C. Sparks (eds.) Information society and civil society. Purdue University, 185-207.

[5] Coombs, Rod, Saviotti, Paolo \& Walsh, Vivien (1992) 'Technology and the firm: The convergence of economic and sociological approaches?', in: Rod Coombs, Paolo Saviotti \& Vivien Walsh (Eds.) Technological change and company strategies: Economic and sociological perspectives. London: Harcourt Brace Jovanovich, 1-24.

[6] Dervin, Brenda (1992) 'From the mind's eye of the user: The sense-making qualitativequantitative methodology', in Jack D. Glazier \& Ronald R. Powell Qualitative research in information management. Englewood: CO:Libraries, 61-84.

[7] Donckels, Rik, Lambrecht, Johan \& Van Lierde, Els (1997) Vijfde Europees KMOobservatorium - Lessen voor België. Brussel: KMO-Studiecentrum.

[8] Etzioni, Amitai (1986) 'Socio-economics: a proposal for a new interdisciplinary field', in: Journal of social behavior and personality, 1(4), 475-482.

[9] European Network for SME Research (1997) European Observatory for SMEs - Fifth Annual Report. s.l.: ENSR - EIM.

[10] Freeman, C. (1994) 'The diffusion of information and communication technology in the world economy in the 1990s', in: R.E. Mansell (Ed.) Management of information and communication technologies: Emerging patterns of control. London: Aslib, 8-41.

[11] FVIB (1998) Strategische analyse van de accountancysector. Brussel: NCMV-FVIB, 10-11 (Internal document)

[12] Glaser, Barney G. \& Strauss, Anselm L. (1967) The discovery of grounded theory Strategies for qualitative research. Hawthorne: Aldine de Gruyter.

[13] Haddon, Leslie \& Silverstone, Roger (1994) 'Telework and the changing relationship of home and work', in: R.E. Mansell (Ed.) Management of information and communication technologies: Emerging patterns of control. London: Aslib, 234-247.

[14] HLEG (1997) Building the European information society for us all - Final report of the High-Level Expert Group. European Commission.

[15] Leeuwis, Cees (1993) Of computers, myths and modelling - The social construction of diversity, knowledge, information and communication technology in Dutch horticulture and agricultural extension. Wageningen: Landbouwuniversiteit Wageningen.

[16] Lobet-Maris, Claire, Delhaye, Renaud, Henrotte Véronique, Walthery, Pierre (1997) (avec la collaboration d'Alain Gofflot \& Béatrice van Bastelaer) Utilisation des systèmes d'informatioin inter-organisationnels par les PME Belges - Rapport final SIO. Namur: CITA-FUNDP.

[17] Mansell, Robin (1996) 'Communication by design', in: Robin Mansell \& Roger Silverstone (Eds.) Communication by design - The politics of information and communication technologies. Oxford: Oxford University Press, 15-43.

[18] Murdock, G., Hartmann, P. \& Gray, P. (1992) 'Contextualizing home computing: Resources and practices', in: R. Silverstone \& E. Hirsch (Eds.) Consuming technologies: Media and information in domestic spaces. London: Routledge, 146-157.

[19] Pierson, Jo (1998) Gericht onderzoek naar gebruik van Intemet en ICT binnen de kleinschalige professionele markt, meer bepaald bij de vrije \& intellectuele beroepen 
(accountancy). Report for Planet Internet as part of the additional consultancy for Medialab, Brussels: VUB-SMIT.

[20] Pierson, Jo (1997) Socio-scientific analysis of supply and user processes concerning information and communication technologies and applications within the small-scale professional sphere. Paper presented at the Workshop of the European Network of Doctoral Studies in Communication and Media (EDICOMM), Madrid, Spain, 30 August-5 September 1997.

[21] Punie, Yves (1997) 'Gebruik van media en informatie- en communicatietechnologie Een interpretatieve benadering van het innovatieproces', in: Jan Servaes \& Valerie Frissen (Eds.) De interpretatieve benadering in de communicatiewetenschap - Theorie, methodologie en case-studies. Leuven: Acco, 251-271.

[22] Punie,Y., Veller, A., Verhoest, P. \& Burgelman, J.C. (1994) La diffusion des innovations telematiques selon le point de vue des utilisateurs: le cas des petits utilisateurs professionels. In: Technologies de l'Information et Société, nr.3, p.219-247.

[23] Sen, Amartya (1995) Welzijn, vrijheid en maatschappelijke keuze - Opstellen over de politieke economie van het pluralisme - Gekozen en ingeleid door Jos de Beus. Amsterdam: Van Gennep.

[24] Silverstone, Roger (1995). Media, communication, information and the 'revolution' of every life. in: Stephan J. Emmott (Ed.). Information superhighways - Multimedia users and futures. Londen: Academic Press, 61-77.

[25] Silverstone, Roger \& Haddon, Leslie (1993). Future compatible? Information and communication technologies in the home - A methodology and a case study. Report prepared for the Commission of the European Communities (RACE Project 2086). Centre for Information and Communication Technologies / University of Sussex, U.K., October 1993, 5-7.

[26] Strauss, A. \& Corbin, J. (1990) Basics of Qualitative Research. Grounded Theory Procedures and Techniques. Newbury Park: Sage.

[27] Wester, Fred (1991) Strategieën voor kwalitatief onderzoek. Muiderberg: Dick Coutinho. 